ARTIGO

\title{
Children, health assets and poverty in a recent post-war scenario: the Angola case
}

\author{
Margarida Gaspar de Matos *; Celso David ${ }^{* *}$; Celeste Simões ${ }^{* * *}$; Luis Tavira*** \\ ${ }^{*}$ Health Psychologist, Expert in International health. Professor at FMH/ UTL (Technical \\ University of Lisbon/ Portugal). Researcher at CMDT/ IHMT/UNL (Institute of Hygiene and \\ Tropical Medicine) \\ ** Master in Special Needs. Senior Lecturer and Coordinator of Special Needs Department. \\ University Agostinho Neto-Benguela/ Republic of Angola \\ ${ }^{* * *}$ Social Psychologist. Professor at FMH/ UTL (Technical University of Lisbon/ Portugal). \\ Researcher at CMDT/ IHMT/UNL (Institute of Hygiene and Tropical Medicine) \\ **** Medical Doctor. Professor at FCM/ UNL (New University of Lisbon/ Portugal). Head of \\ CMDT/ IHMT/UNL (Institute of Hygiene and Tropical Medicine)
}

Correspondence

\begin{abstract}
Angola is a Portuguese-speaking country that faced a recent civil war, after decades of colonial occupation and conflict, and still exhibits a scenario of poverty. Well-fare, health concerns and schooling are still a privilege.

A school-based survey was carried out in all four schools in Benguela (South of Angola), 22 randomly classes were selected, including 701 pupils, attending 8th and 10th grade, being $55.2 \%$ boys. Mean age in the present study was 17.5 years old, SD 3.25.

Descriptive and multi-variated analysis revealed that the perception of family well fare is mainly associated with positive aspects of health: fruit intake, perception of school competence, mother instruction level and number of friends. Life satisfaction was associated with family well fare, as well as with mother level of instruction, fruit intake and perception of safety in school.

The health assets' perspective seems thus to propose a new way of identifying and fulfilling needs in a developing country. Present results suggest a focus on positive issues such as schooling, social capital/friends, and healthy food, as relevant factors to promoting teens' health and well-being, in a country in a recent post-war scenario.
\end{abstract}

REVISTA BRASILEIRA DE TERAPIAS COGNITIVAS, 2008, Volume 4, Número 2 
Keywords: Children, Adolescents, Poverty, Health concerns, Schooling, Well-being.

\section{RESUMO}

Angola é um país de língua oficial Portuguesa que enfrentou recentemente uma guerra civil depois de décadas de ocupação colonial. O bem-estar económico, as preocupações com a saúde e a escolarização são ainda um privilégio de poucos.

Um estudo em meio escolar foi realizado em quarto escolas em Benguela (Sul de Angola). 22 Escolas foram aleatoriamente seleccionadas, incluindo 701 alunos do oitavo e o $10^{\circ}$ ano de escolaridade, $55.2 \%$ dos participantes eram rapazes. A idade média foi 17.5 anos, com um DP de 3.25.

Uma análise descritiva seguida de uma análise multivariada revelou que a percepção de bem-estar económico da família foi sobretudo associada com aspectos positivos da saúde: consumo de frutas, percepção de competência escolar, o nível de instrução da mãe e o número de amigos. A satisfação com a vida associou-se ao bem-estar económico da família, bem como ao nível de instrução da mãe, ao consumo de fruta e à percepção de segurança na escola

Identificar e mapear os "trunfos para a saúde" parece pois uma visão promissora. Sublinhase a necessidade de focar aspectos positivos da vida das pessoas, tais como a escolarização, o capital social, a alimentação saudável, na promoção da saúde e bem -estar dos jovens.

Palavras-chave: Crianças, Adolescentes, Pobreza, Cuidados com a saúde, Escolaridade, Bem-estar.

\section{Introduction}

Several researches point out that poverty is related to poor health, lack of hope and expectations as well as poor well-being (Duncan, 1998; McLoyd, 1998; Newacheck et al., 2004; Mitka, 2005; Matos, 2005). There is evidence of continuity across two generations, in half of the socio-economic disadvantaged families, in what concerns intelligence, academic achievement, occupation, crime and psychiatric disorders (Garmezy, 1991).

Duncan (1998) related income-based poverty to other conditions associated with low socioeconomic status such as low level of parental schooling, and living in certain poor neighbourhoods; income levels (at least to a certain extent), for instance, tends to reduce parental stress and improves children-parental relationships.

Nevertheless, as Mcloyd (1998) stressed, there are other environmental factors that constitute important mediators of income and economic effects, such as quality of schooling, and level of academic and language stimulation that children have at home. The Child Care quality (i.e. motivated teachers, peer support, parental support, safe school

REVISTA BRASILEIRA DE TERAPIAS COGNITIVAS, 2008, Volume 4, Número 2 
environment and physical health) is related to better achievement and increased perception of well being (Huston, 1998; Halfon \& Inkelas, 2003).

Angola is a Portuguese speaking country that faced a recent civil war after decades of colonial occupation and conflict, and still exhibits a scenario of poverty and poor socioeconomic development. Yet individuals tend to value health assets (Morgan, 2007) and adapt daily routines, to study, and to develop expectations that go far beyond survival.

The media often present dramatic scenarios of destroyed houses and lack of basic health facilities, which indeed can be confirmed in site visits, yet locals have learned to put their lives on hold and aim at recovering positive routines in order to feel good, not just "not bad". In fact, nine years after a civil war, and after decades of armed conflicts, schooling is still a privilege: the present school-based study has surely a socio-economic status's bias.

Social and political situation in Angola reflects a vertiginous and unregulated transition from a planned to a market economy, and from a war to a peace scenario.

In Angola, about two thirds of the school-aged individuals are out of the regular school system, $40 \%$ being females. Several schools were destroyed during civil war, and there are many unsolved problems in the area of basic education and health.

Rural areas inhabitants survive with a daily income under one USD (Dollars from the United States of America), and $67 \%$ of the total population lives under extreme poverty levels (Minjud, 2006). Benguela, in the centre of Angola is now considered a poor town, in part due to massive internal displacement towards the littoral town, because of the exodus of the general population from the "outback", and from the way that the country was split politically during civil war. Most of the humanitarian health and educational actions were carried out in the last decades, mostly by foreign NGOs' (Non Governmental Organizations) that in general are not aware of cultural issues and belief systems in Benguela.

Angola is a county of rich and diverse ethnical groups where during puberty different adolescent social and sexual behaviour are expected (Resolução AFR/RC, 2003).

It is impossible to understand adolescents aside from History and socio-economic issues in each country or culture. In a war scenario, adolescents also discover their body and sexual drives, as well as love and fear; they search for a personal and social identity and meaning, and they take health risks. War and armed conflicts are "just" other features of a country ecological context.

Academic achievement is an important feature in countries where education it is available universally, and a several researches relate schooling to better health access and expectation, especially personal schooling and mother level of instruction.

According to the World Youth Forum (African Youth Forum, 2000), adolescents health problems are very serious in Angola region (Southern African developing Countries/ S.A.D.C) mainly STD, unplanned pregnancy and abortion, poor nutrition, parasitosis, malaria, cholera, substance use, depression, self and interpersonal violence. In addition, children marriages and sexual initiation practices clearly violate youth rights. In general, it was argued that Southern Africa is unable to meet adolescents' needs in the area of education, health and development (Minjud, 2006).

REVISTA BRASILEIRA DE TERAPIAS COGNITIVAS, 2008, Volume 4, Número 2 
Following the World Youth Forum (African Youth Forum, 2000), youths are unevenly exposed to health risks, according to gender, age, nutritional status, civil status schooling and employment, and even considering places where they spend time. UNAIDS/Angola's (UNAIDS, 2004) last report sets the HIV/aids prevalence at 3.9\%. Civil war provided in a way a momentary specific protection that soon will disappear, with peace and recently open borders, namely to Congo, one of the countries with highest prevalence of AIDS in Africa.

Angola, has about 4 millions national migrants, now trying to reach homelands, mostly they have poor schooling (more than half of the population has no schooling at al), early contact with a military culture, and they are very young (about $70 \%$ of Angolan have less than 24 years old). Angolan also have a high level of poverty, lack of female rights, equity and autonomy, destroyed social support nets, the second highest rate of fertility and $70 \%$ of women at 20 years old have at least one child (Minjud, 2006; African Youth Forum, 2000).

UNAIDS/Angola (2004), point out that $84 \%$ of new HIV infected have between 20 and 49 years old, typically the most powerful economical productive age group, and infection prevalence is increasing in women, young people and children. In another hand, in Angola, nutrition poverty is still a main morbidity and mortality factor. (Minjud, 2006)

Health promotion includes poverty reduction and has to be a broad social and political process that includes strengthening of individual capacities and the chance of environmental impacts (Matos, 2005; Matos \& Equipa Aventura Social, 2003; 2006). "Children in the streets" accept any economical rewarding activity to survive and sometimes to help their families (Roca, 2000). However, as Morgan (2007) claimed, adolescents are searching for positive aspects of daily life, searching for life satisfaction and value schooling; they are not only trying to survive.

Poverty has a strong impact on school performance and mental well-being during childhood, especially when associated to poor parental education and exposure to stressful events (Mcloyd, 1998; Feigin, 2005). Mother education is associated to children health, better housing and better nutrition (LeVine, LeVine, Richman, Uribe \& Correa, 1994). Perrin (1989) referred a study where mothers that are more educated tend to have healthy children. However, as Perrin also point out, poverty and lack of education are not fix population's characteristics, but they are rather temporary situations, which can be properly addressed and overcame, with adjusted actions. (Mechanic, 1994; Naidoo \& Wills, 2000; OMS, 2002)

Inequity and poverty are related to poor schooling and poorer healthy life styles. Individuals that live in poor countries struggle to survive and preserve human rights and questions such as schooling and health nutrition tend to be a second step (Matos, 2005; Over, Ellis, Huber \& Orville, 1992; Phillips \& Verhasselt, 1994; PNUD, 2003; STEP/BIT, 2003; WHO, 1997).

Besides regular developmental challenges, adolescents facing specific challenges are thought to present further difficulties that can be increased in the presence of negative live events (WHO, 2001).

If it is well documented that children and adolescents that live in poverty tend to be exposed to higher biological risks (Garmezi, 1993), other authors insisted that environmental factors are associated to the way children and adolescents make sense of one's life and life events, thus becoming vulnerable or resilient (Grotberg,1995). Vulnerability comes from exposure to adverse situations (Masten, 1997). Usually factors are 
interrelated and co-exist, yet impact on children and adolescent health is related to intensity and length (Hampton, 2006). A central issue in research on resilience is the number of risk factors that threaten the adolescents' adjustment. This aspect, known as the cumulative risk, stresses the impact of quantitative, more than the qualitative, aspect of risk. It seems that the presence of four or more risk factors is connected to maladjustment. Yet, poverty or socio-economic disadvantage is frequently among these "four or more" factors (Forehand, Bigger \& Kotchick, 1998; Masten et al., 1988; Werner \& Smith, 2001; Simões, Matos, Tomé \& Ferreira, 2008). The way adverse situations become associated to vulnerability or resilience, seem related to personal factors such as positive peer bonds and school achievement (Masten, 1997; Resnick et al., 1997).

A participative life in school, as well as the perception of safety in schools, the feeling of belonging to schools and the bonding effect with teachers and pupils, are relevant factors both in well being and on academic success improvement. (Matos et al., 2003; 2006; Simões, 2007).

Poverty or economical inequity affects health either by reducing access to health and educational services or by narrowing life expectation towards the future (Matos, 2005). As Morgan (2007) pointed out, communities have never been built upon their deficiencies, and community building depends on mobilising capacities and assets of people and places.

Scales (1999) identified 40 health assets to be promoted in communities, which include positive future, family support, schools involvement, integrity and caring school climate. It seems thus necessary to map young people health assets, in order to identify what facts or factors they perceive as associated with their well being and personal development

The aim of the present survey is (1) to study the state of art of health protective and compromising behaviours of young school pupils in Benguela; and (2) to identify associations between a set of health related behaviours and perceived economic wellness and perceived life satisfactions.

\section{Methods}

Participants

A school-based survey was carried out in Benguela (South of Angola), including 701 pupils, in 22 randomly selected classes from all four schools in town, attending 8th and 10th grades. This sample is representative of pupils that attend those grades, at public school, in Benguela.

Pupils are older than usual pattern, according to school grade (mean age 17.5 years old, SD 3.25), when compared e.g. to Portuguese national HBSC study (Matos et al., 2003; 2006), being $55.2 \%$ boys, whereas in general in Europe girls are in greater number (Currie, Hurrelmann, Settertobulte, Smith \& Todd, 2000; Currie et al., 2004). Most of those youngsters have Angolan nationality $(97.0 \%)$, and $93.0 \%$ considered themselves to be "black".

Procedures

REVISTA BRASILEIRA DE TERAPIAS COGNITIVAS, 2008, Volume 4, Número 2 
The sampling unit used in this survey was the class. Teachers administered the questionnaires in the classroom. Pupils' participation in the survey was voluntary; however, no instances of refusal were reported. Pupils who were absent from school on the day of the survey were not included. Pupils completed the questionnaires on their own and teachers were only allowed to help with administrative procedures and left their anonymous questionnaires in a large envelope. This study followed international rules for ethic procedures including parents' informed consent (passive).

Instrument

The Health Behaviour in School - Aged Children (HBSC) questionnaire

A version of the international survey Health Behaviour in School - Aged Children (HBSC) (Currie et al., 2000; 2004), Portuguese translation (Matos et al., 2003; 2006) was used, adapted to Angolan context, by a panel of experts from both Angola and Portugal. The questionnaire consisted of two parts, the main HBSC survey questionnaire that included questions on demographics (age, sex and socio-demographics, nationality, ethnicity perception), school ethos, tobacco and alcohol use, physical activity and leisure, nutrition, safety, aspects of psychosocial health, general health symptoms, social relations and social support, questions on drug use, and attitudes and knowledge about AIDS. Questionnaires required approximately 55 minutes completing.

The "Statistical Package for Social Sciences - SPSS - Windows" (version 15.0) was used. Will be presented descriptive general analysis followed by two multiple regressions analysis.

For the purpose of the present study, besides demographic variables such as gender and grade, the following variables will be considered: (1) parental instruction (father and mother) (see table 1), (2) perception of life satisfaction, a 0 to 10, Cattril ladder (Cattril, cit. Matos et al., 2003); (3) perception of safety in school, ranged from 1 never, to 5 always; (4) number of good friends, ranged from none, one, two, three or more; (5) healthy food: fruit intake ranged from never to everyday, five options; (6) teacher perception of school competence ranged above average, average, good, very good; (7) perception of family economic well being, ranged very bad, rather bad, average, good, very good; (Questions' source: HBSC questionnaire, Currie et al., 2000; 2004).

\section{Results and Discussion}

Percents for variables in study are displayed Table 1 and 2.

Table 1- Parents level of schooling; perception of family economic status 


\begin{tabular}{lccccl}
\hline & $\begin{array}{l}\text { Never } \\
\text { studied }\end{array}$ & $\begin{array}{l}\text { Studied } \\
\text { 4years }\end{array}$ & $\begin{array}{l}\text { Studied } \\
\text { 9years }\end{array}$ & $\begin{array}{l}\text { Studied } \\
\text { 12 years }\end{array}$ & Graduation \\
\hline $\begin{array}{l}\text { Father } \\
(\mathbf{n}=\mathbf{5 8 7})\end{array}$ & $8.0 \%$ & $18.1 \%$ & $19.3 \%$ & $24.0 \%$ & $30.7 \%$ \\
$\begin{array}{l}\text { Mother } \\
(\mathbf{n}=\mathbf{5 8 4})\end{array}$ & $14.9 \%$ & $23.8 \%$ & $29.6 \%$ & $20.9 \%$ & $10.8 \%$ \\
\hline
\end{tabular}

Table 2 - Dependent variables included in the present study (frequencies) 


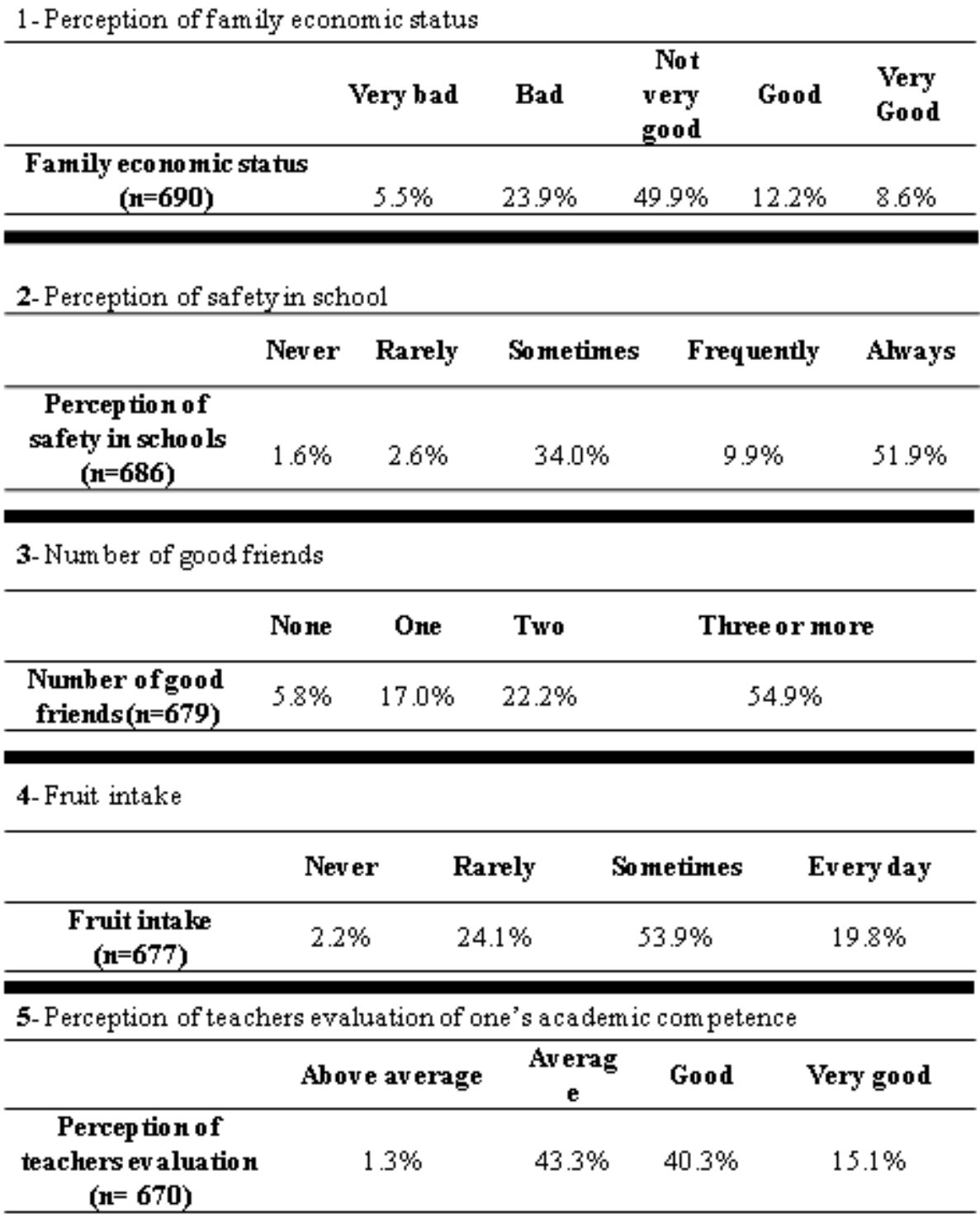

Mean value for perception of life satisfaction was 6.2, with a standard deviation of 2.8 . Parental schooling is rather low, especially for mothers. Yet, it was expected that those pupils correspond to a rather privileged group, since it is estimate that only one third of the school-aged children and adolescents go to school (Minjud, 2006). According to Angolan situation, the present sample actually corresponds, as mentioned earlier, to educationally privileged adolescents and young pupils: those who go to school. With this bias in mind two multiple regressions were held to identify variables associated to pupils' perception of life satisfaction, and pupils' perception of family economic well being.

REVISTA BRASILEIRA DE TERAPIAS COGNITIVAS, 2008, Volume 4, Número 2 
Predicting perception of life satisfaction from the remaining variables in study an adjusted model was found $[F(4,415)=27.32, p<.001]$, explaining $20 \%$ of total variance $(R 2=.201)$, and including the following variables (Multiple Regression model, stepwise): perception of family economic well being $(\beta=.342, p<001)$; school safety $(\beta=.133 ; p<.01)$, mother instruction $(\beta=.109 ; p<.05$, and fruit intake $(\beta=.100 ; p<.05)$ and excluding father level of instruction, number of good friends, and perception of teachers evaluation of school competence.

Predicting perception of family economic well being from the remaining variables in study an adjusted model was found $[F(5,415)=19.25, p<.001]$, explaining $25 \%$ of total variance, $\left(\mathrm{R}^{2}=.250\right)$, and including the following variables (Multiple Regression model, stepwise): perception of life satisfaction $(\beta=.310, p<.001)$; fruit intake $(B=.182 ; p<.001)$; perception of school competence $(\beta=.173, p<.001)$; number of close friends $(\beta=.121, p<.005)$ mother instruction $(\beta=.100 ; p<.05)$, and excluding father level of instruction and perception of safety in school.

Results revealed thus that the perception of family economic well being was mainly associated with positive aspect of health: fruit intake, perception of school competence, mother instruction level and number of friends. Life satisfaction is also associated with variables that stressed positive aspect of life. Perception of life satisfaction and perception of family economic well being are strongly associated, and both associated to mother instruction level and fruit intake. However, in the case of perception of life satisfaction, safety issues seem more salient, while in the case of perception of family well being, the number of close friends and the academic achievement seemed more relevant. Adolescents in the present study seemed concerned about positive aspects of daily life, searching for life satisfaction, valuing schooling and social support/friends.

Some authors (Duncan, 1998; McLoyd, 1998) related poverty with low level of parental schooling, and level of academic and language stimulation that children can have at home. Peer support was related to increased perception of well being (Newacheck et al., 2004).

In the present study, both regression models claim for the importance of mother instruction level. Mother education is usually associated to children health, better housing and better nutrition (LeVine et al., 1994). Here, fruit intake is a consistently associated with either economic well being perception or perception of life satisfaction.

Masten and Coatsworth (1998) pointed out that the way adverse situations become associated to vulnerability or resilience, seem related to personal factors such as positive peer bonds and school achievement. In the present study, although a socio-economic vulnerability is doubtless present, factors like perception of school achievement and social support (number of close friends) appeared associated with life satisfaction.

\section{Conclusions}

The health assets perspectives highlight a new way of identifying and fulfilling needs in developing countries. It is commonly accepted and documented that inequity and poverty is related to poor schooling and poorer healthy life styles. People living in poor countries struggle so hard to survive that some authors claim that questions such as schooling and

REVISTA BRASILEIRA DE TERAPIAS COGNITIVAS, 2008, Volume 4, Número 2 
health nutrition tend to be a second issue (Matos, 2005; Over et al., 1992; PNUD, 2003; SEP/BIT, 2003). Yet, in a post-war scenario, the present results suggest a search for personal positive meaning and well-being: personal and family schooling, social capital/friends, and healthy food.

Poverty or economical inequity affects health, either by reducing access to health and educational services or by narrowing life expectation towards the future (Matos, 2005), yet, recent claims such as Morgan's (2007), defend that community building depends also on mobilising capacities and assets of people and places.

Poverty, especially when associated to poor parental education and exposure to stressful events, has a strong impact on school performance and mental well-being (McLoyd, 1998; Feigin, 2005), and specially mother education, was frequently associated to children health, better housing and better nutrition (LeVine et al., 1994; Williams, Baumslag \& Jelliffe, 1994; Perrin, 1989). The present results point out in the same direction.

In the present study were found some of Scales' (1999) health assets to be promoted in communities, that including positive future (schooling, peer support), family support (less family stress, better mother schooling and jobs), schools involvement, integrity, and caring school climate (peer support, safety in school and school competence).

Results stressed the need to map young people's health assets, in order to identify what facts or factors they perceive as associated with their well being and personal development, even in specially difficult socio-cultural situations such as in a country that recently come through decades of war.

Harforf (2006) argued that, although economists can have problems explaining it clearly, economists deal with real people, and economic development is really about a better life for people - more choices, less fear, less suffering and deprivation, more health and more education opportunities for all.

Socio-economic and socio-cultural development aim at reducing poverty, lowering child mortality, increasing life expectancy at birth, access to education, health care, jobs and housing. However, the final aims of development are indeed personal and social well being. This is a critical issue specially when designing health-based interventions in the so-called "Developing Countries" (Matos, 2005). Furthermore, according to Perrin (1989), the poverty and the lack of education are not steady population characteristics, but temporary situations that can be properly addressed and overcome, with adjusted actions (Mechanic, 1994; Naidoo, 2000; OMS, 2002).

Angola, as well as many other Developing Countries, is far from reaching universal quality teaching "for all". Yet, investing in adolescents' (future mothers) academic achievement, empowering teens with strategies to promote their health and personal and social well being, seems an appropriate strategy to deal with reducing poverty and increasing choices: the key words of our work are, no matter how bad a social context appears to be, promoting women's (mothers') education is a priority, as well as promoting positive health food habits (in this case fruit intake), and encouraging social capital and social cohesion, that is increase the social support and the sense of belonging.

REVISTA BRASILEIRA DE TERAPIAS COGNITIVAS, 2008, Volume 4, Número 2 
Angola is just making the first steps in the area of research and health promotion: further action and further research is thus recommended from now on, both at a micro-level, implementing (positive) health interventions in schools. Those interventions would include teachers, pupils and families and would focus on pro-active and positive health/well-being issues, such as healthy lifestyles, personal and social competence and social support), and at a macro-level investing broadly on schooling "for all". As said in previous studies (Feigin, 2005; McLoyd, 1998; LeVine et al., 1994; Williams et al., 1994; Perrin, 1989) education is one of the best, if not the best, capital for future well-being, well fare and health. The final aim is to reduce poverty and increase personal competence, social participation, hope and future expectation, and thus meet the concerns of a Positive (Health) Psychology.

\section{References}

African Youth Forum. (2000). African Youth and Health AYF/UNS.

Currie, C., Hurrelmann, K., Settertobulte, W., Smith, R. \& Todd, J. (2000). Health and health behavior among young people. Copenhagen: World Health Organization.

Currie, C.; Roberts, C.; Morgan, A.; Smith, R.; Settertobulte, W.; Samdal, O. \& Rasmussen, V. (2004). Young people health in context. Copenhagen: WHO.

Duncan, G. (1998). Paper presented at the "Growing up poor: The effects on achievement, parenting and child care", Consortium of Social Science Associations, Washington.

Feigin, R. D. (2005). Prospects for the Future of Child Health Through Research. JAMA, 294, 1373-1379.

Forehand, R.; Biggar, H. \& Kotchick, B. A. (1998). Cumulative risk across family stressors: Short- and long-term effects for adolescents. Journal of Abnormal Child Psychology. Retrieved 20-09-2002, from www.findarticles.com

Garmezy, N. (1991). Resiliency and vulnerability to adverse developmental outcomes associated with poverty. American Behavioral Scientist, 34 (4), 416-430.

Garmezy, N. (1993). Children in poverty: Resilience despite risk. Psychiatry, 56, 127-136.

Grotberg, E. H. (1995). A guide to promoting resilience in children: Strengthening the human spirit. The Hague: The Bernard van Leer Foundation.

Halfon, N. \& Inkelas, M. (2003). Optimizing the Health and Development of Children. JAMA, 290, 3136-3138.

Hampton, T. (2006). Researchers Seek Roots of Resilience in Children. JAMA, 295, 1756-1760

Harford, T. (2006). O Economista Disfarçado. Lisboa: Ed Presença,

REVISTA BRASILEIRA DE TERAPIAS COGNITIVAS, 2008, Volume 4, Número 2 
Huston, A. (1998). Paper presented at the "Growing up poor: The effects on achievement, parenting and child care", Consortium of Social Science Associations, Washington.

LeVine, R.; LeVine, S.; Richman, A.; Uribe, F. \& Correa, C. (1994). Schooling and survival: the impact of maternal education on health and reproduction in the third world. In: L. Chen; A. Kleinman \& N. Ware (Orgs.). Health and Social Change in International perspective (pp. 303-338). Boston: Harvard Press.

Masten, A. S. (1997). Resilience in children at risk. Research and practice, 5(1), 4-6.

Masten, A. S. \& Coatsworth, J. D. (1998). The development of competence in favourable and unfavourable environments. American Psychologist, 53(2), 205-220.

Masten, A. S.; Garmezy, N.; Tellegen, A.; Pellegrini, D. S.; Larkin, K. \& Larsen, A. (1988). Competence and stress in school children: The moderating effects of individual and family qualities. Journal of Child Psychology and Psychiatry, 29(6), 745-764.

Matos, M. G. (2005). Comunicação e gestão de conflitos e saúde na escola. Lisboa: CDI/FMH.

Matos, M. G. \& Equipa do Projecto Aventura Social. (2003). A saúde dos adolescentes portugueses (Quatro anos depois). Lisboa: Edições FMH.

Matos, M. G. \& Equipa do Projecto Aventura Social. (2006). A saúde dos adolescentes portugueses: Hoje em 8 anos. Retrieved 20-12-2006, from http://www.fmh.utl.pt/aventurasocial/pdf/191206/nacional.pdf

McLoyd, V. (1998). Socioeconomic disadvantage and child development. American Psychologist, (53), 185-204.

Mechanic, D. (1994). Promoting health: Implications for modern and developing nations. In: L. Chen; A. Kleinman \& N. Ware (Orgs.). Health and Social Change in International perspective (pp. 471-490). Boston: Harvard Press.

Minjud. (2006). Campanha de Sensibilização Sobre o VIH/SIDA. Luanda: Unicef/Angola.

Mitka, M. (2005). Efforts to Meet World Health Goals Lag. JAMA, 294, 1600-1603.

Morgan, A. (2007). Frameworks for improving young people's mental well being: assets and deficits Models. Paper presented at the WHO/HBSC Forum, March 2007, Las Palmas.

Naidoo, J. \& Wills, J. (2000). Health promotion foundations for practice. London: Bailliere Tindall.

Newacheck, P. W.; Park, M. J.; Brindis, C. D.; Biehl, M. \& Irwin, C. E. Jr. (2004). Trends in Private and Public Health Insurance for Adolescents JAMA, 291, 1231-1237.

OMS. (2002). Rapport sur la santé dans le monde "Réduire les risques et promouvoir une vie saine". Genève: OMS

REVISTA BRASILEIRA DE TERAPIAS COGNITIVAS, 2008, Volume 4, Número 2 
Over, M.; Ellis, R. P.; Huber, J. \& Orville, S. (1992). The consequences of Adult Ill-health. In: R. Feachen; T. Kjelltrom; C. Murray; M. Over \& M. Phillips (Orgs.). The health of adults in the developing world (pp. 161-208). NY: Oxford Press.

Perrin, B. (1989). Literacy and health: making the connection. Health promotion, 28, 2-5.

Phillips, D. \& Verhasselt, Y. (1994). Health and Development. NY: Routledge

PNUD. (2003). Relatório do desenvolvimento Humano 2003: Objectivos de desenvolvimento do milénio- um pacto entre nações para eliminar a pobreza humana. Lisboa: IPADMensagem.

Resnick, M. D.; Bearman, P.; Blum, R. W.; Bauman, K. E.; Harris, K. M.; Jones, J.; Tabor, J.; Beuhring, T.; Sieving, R. E.; Shew, M.; Ireland, M.; Bearinger, L. H.; Udry, J. R. (1997). Protecting children from harm. Journal of the Medical Association, 278(10), 823-832.

Resolução AFR/RC 45/R7. (2003). Estratégias para a Região Africana. Luanda: Comité Regional Sobre Saúde dos Adolescentes e Jovens.

Roca, Z. (2000). As Crianças de Rua em Angola: Um Estudo das Necessidades e dos Potenciais para a introdução do Ensino Básico Informal e da Formação Profissional. Lisboa: Edições Universitárias Lusófonas.

Scales, P. C. (1999). Reducing risks and building developmental assets. Journal of School Health, 69 (3), 113-119.

Simões, C.; Matos, M. G.; Tomé, G. \& Ferreira, M. (2008). Impact of Negative Life Events on Positive Health in a population of adolescents with special needs, and protective factors. Journal of Cognitive and Behavioral Psychotherapies, 8, 1, 53-65.

Simões, C. (2007). Comportamentos de risco na adolescência. Lisboa: FCG/FCT.

STEP/BIT. (2003). A Luta Contra a Pobreza e a Exclusão Social: experiências do Programa Nacional de Luta Contra a Pobreza. Genebra: Bureau Internacional do Trabalho.

Unaids / Angola / Who Epidemiological. (2004). Fact Sheet On VIH/AIDS and Sexually Transmitted Infections. from http//www.unaids.org

Werner, E. E. \& Smith, R. S. (2001). Journeys from childhood to midlife: Risk, resilience and recovery. New York: Cornell University Press.

WHO. (2001). The World Health Report. Genève: World Health Organization.

WHO. (1997). The Jakarta Declaration: On Leading Health Promotion into the 21st Century. Genève: World Health Organization.

Williams, C.; Baumslag, N. \& Jelliffe, D. (1994). Mother and Child Health. NY: Oxford Press. 
团Correspondence

Endereço do autor principal: Margarida Gaspar de Matos. FMH/UTL.

Estrada da Costa Cruz Quebrada, 1499 Lisboa CODEX. Portugal.

E-mail: margaridagaspar@netcabo.pt.

Tel +351214149152.

Recebido em: 16/04/2008

Aceito em: 15/07/2008 